EGALITA, Jurnal Kesetaraan dan Keadilan Gender, Pusat Studi Gender (PSG) Universitas Islam Negeri Maulana Malik Ibrahim Malang. Copyright @ 2009 . Vol. IV Nomor 2 Tahun 2009 : 178 - 184

\title{
PEREMPUAN DAN MATEMATIKA
}

\author{
Makkulau \\ Jurusan Matematika FMIPA Universitas Haluoleo, Kendari \\ Telepon: 08135475144 \\ E-mail:makkulau@statistika.its.ac.id
}

\begin{abstract}
Abstrak
Gender gap was influenced mathematical ability between boys and girls. Stereotypes about women's position lower in mathematics is a contrasting landscape and different from the data and scientific facts. The result of research in 69 countries with gender equality shows that teenage girls tend to have a math test scores higher. In addition, young women also tend to do about the matter of better and more confident in their ability in the field of math. The results of this study also showed that young women have the same ability with young men when they are given an equal education, especially in mathematics.
\end{abstract}

Kesenjangan gender ternyata berpengaruh terhadap kemampuan matematika antara anak laki-laki dan perempuan. Stereotipe mengenai posisi perempuan yang lebih rendah di bidang matematika merupakan pemandangan yang kontras dan berbeda dengan data dan fakta ilmiah. Hasil penelitian di 69 negara dengan kesetaraan gender menunjukkan bahwa remaja putri cenderung mempunyai skor tes matematika yang lebih tinggi. Selain itu, remaja putri juga cenderung mengerjakan soal hitungan dengan lebih baik dan lebih percaya diri dalam kemampuannya di bidang pelajaran matematika. Hasil penelitian ini juga menunjukkan bahwa remaja putri mempunyai kemampuan yang sama dengan remaja putra saat mereka diberikan pendidikan yang setara khususnya di bidang matematika. 
Keywords: kesenjangan gender, matematika, stereotip, data dan fakta ilmiah.

\section{Pendahuluan}

Perbedaan jenis kelamin secara biologis seringkali membuat salah satu pihak diperlakukan tidak adil dalam ruang sosial. Perempuan dengan berbagai aspek-aspek kodratinya selalu diposisikan dalam ruang domestik (kelas dua). Sedangkan laki-laki biasanya lebih diposisikan dalam ruang publik (kelas satu). Pengidentifikasian semacam ini sesungguhnya adalah praktik dari ketidakadilan gender (bukan ketidakadilan seks), seolah-olah perempuan yang mengurus rumah tangga diasumsikan tidak mampu mengurusi persoalan-persoalan di ruang publik yang menyangkut kepentingan orang banyak. Dalam faktanya, bukan tidak mungkin perempuan juga memiliki kemampuan untuk mengaktualisasikan dirinya di ruang publik sebagaimana halnya laki-laki.

Hasil penelitian dari Nicole ElseQuest yang dipublikasikan di jurnal Psychological Bulletin, peneliti menganalisis data 493.495 pelajar dari 69 negara. Para pelajar berusia antara 14-16 dan pernah ambil bagian dalam dua studi, the Trends in International Mathematics and Science Study dan the Program for International Student Assessment menunjukkan bahwa remaja putri mempunyai kemampuan matematika yang sama baiknya dengan remaja putra, akan tetapi remaja putri masih kurang percaya diri (PD) dibanding remaja putra dengan kemampuan matematika mereka. Peneliti juga menemukan bahwa di negara-negara dengan kesetaraan gender, remaja putri cenderung mempunyai skor tes matematika yang lebih tinggi. Selain itu, remaja putri juga cenderung mengerjakan soal hitungan dengan lebih baik dan lebih percaya diri dengan kemampuan matematika mereka jika mereka hidup di negara-negara yang memiliki banyak peneliti perempuan. Hal ini ini membantah stereotipe mengenai kemampuan perempuan yang lebih rendah di bidang matematika. Hasil penelitian ini juga menunjukkan bahwa remaja putri mempunyai performa yang sama dengan remaja putra saat mereka diberikan pendidikan yang setara dan mempunyai panutan perempuan yang jelas di bidang matematika (Nurfajri, 2008).

Hal ini menunjukkan bahwa partisipasi dan peran perempuan dalam bidang sains dan pembuat kebijakan sains dewasa ini mulai diperhitungkan. Pernyataan ini didukung juga dari data statistik tentang gender dan ilmu pengetahuan dan teknologi yang disusun oleh Kelompok Kerja gender dan 
Iptek PAPIPTEK-LIPI dan Kelompok Kerja Convention Watch, Universitas Indonesia yang memperlihatkan bahwa persentase kelulusan perempuan di fakultas MIPA dan teknik melalui UMPTN (Ujian Masuk Perguruan Tinggi Negeri sebelum menjadi SPMB) cukup tinggi dibandingkan yang laki-laki (Ikarowina, T., 2008).

Dari penelusuran literatur, banyak ilmuwan-ilmuwan perempuan yang telah menghasilkan karya-karya sains yang spektakuler baik pada bidang fisika, kimia, biologi maupun matematika. Ilmuwan-ilmuwan perempuan ini sebenarnya cukup banyak dan prestasi mereka hasilkan tidak bisa hanya dipandang sebelah mata oleh komunitas sains pada saat mereka hidup.

Sebagai contoh beberapa ilmuwan perempuan adalah Cecilia PayneGaposchkin yang merupakan orang pertama yang menyatakan bahwa komposisi terbesar alam semesta adalah hidrogen (Horn, 2001). Disertasinya pada tahun 1925 di departemen astronomi Universitas Harvard berjudul "Stellar Atmospehere" berisi teori mengenai komposisi kimia bintang. Selain itu ada pula ilmuwan perempuan pada bidang fisika sperti Jocelyn BellBurnell sebagai orang pertama yang menemukan pulsar. Rosalind Franklin yang menghasilkan foto DNA. akan tetapi keberadaan mereka selama ini secara sengaja dikecilkan bahkan sampai tidak terlihat. Hal itu dilakukan karena selama ini sains menjadi alat otoritas dalam mengkonstruksi gender yang bias. Bukan karena tidak ada perempuan dalam sains, melainkan karena pengetahuan dan rasionalitas mereka tidak diakui oleh budaya sains (Hubbard, 1990 dan Harding, 1991).

Sains bukanlah bagian dari pengetahuan abstrak melainkan suatu pemahaman manusia terhadap alam dan dirinya sendiri. Science berasal dari bahasa Latin scientia (scire, belajar, mengetahui) yang berarti proses bagaimana manusia mengetahui dan memahami dunia fisik dan alam yang mereka tempati (Shepherd, 1993). Sains menurut Sheldon Glashow (1992), fisikawan penemu quark, secara sederhana meliputi matematika, fisika, kimia, astronomi dan kosmologi.

Argumen terakhir menekankan bahwa sains sebagai bagian dari aktivitas budaya untuk memahami dan menemukan solusi dari situasi yang dihadapi manusia. Cara pandang sains dominan suatu logika berpikir berdasar skema persepsi-teori-eksperimen-uji coba untuk mencapai obyektivitas sehingga dapat melahirkan suatu kebenaran umum di bumi dan kosmos. Tujuan yang ingin dicapai adalah memanipulasi dunia untuk kepentingan manusia dan menemukan keteraturan supaya dapat membentuk prediksi akurat sehingga manusia dapat mengatasi dan mengendalikan lingkungan- 
nya.

Selain itu cara pandang sains yang dominan telah menempatkan pola pembe-lajaran yang dilekatkan pada perempuan dan karakter feminin pada posisi dua. Akibatnya, perempuan kurang percaya diri terhadap ide dan kemampuan intelektual yang mereka miliki sehingga tidak dapat dengan leluasa mengakui dan mengembangkan intuisi dalam dirinya. Cara pandang itu juga membentuk budaya komunitas (pola komunikasi dan kode pergaulan) jurusan matematika yang maskulin. Alhasil, perempuan yang ingin bertahan di dalamnya perlu melakukan strategi fragmentasi dengan mengadopsi karakter dominan. Pada perkembangannya, karakter dominan itu bertransformasi menjadi identitas diri (Tharp dan Gallimore, 1988).

Selama ini beberapa pemangku kepentingan melihat isu gender dalam pendidikan khususnya matematika sebagai suatu hal yang berada di luar jangkauan kebijakan formal karena lebih erat dengan masalah sikap dan keyakinan gender pribadi.

Padahal dari data BPS pada tahun 2007, menunjukkan bahwa lebih dari $50 \%$ populasi penduduk indonesia adalah perempuan. Berdasarkan realita ini maka pemerintah perlu memberikan perhatian lebih besar pada sosialisasi matematika yang ramah gender dan bukan merupakan ilmu pengetahuan eksklusif.

\section{Tujuan Penelitian}

Tujuan penelitian ini adalah ingin diketahui tingkat literasi siswa perempuan terhadap pelajaran matematika sehingga mampu mendorong munculnya kepekaan terhadap masalah gender dalam mempelajari matematika sebagai bagian dari pendidikan adil gender dalam masyarakat sains.

\section{Pembahasan}

Matematika diidentikkan dengan rumus dan pembuktian-pembuktian yang abstrak dan susah yang sifatnya subyektif dan pengabaian intuisi yang dianggap sebagai kecenderungan maskulin. Akhirnya, sekelompok perempuan yang memilih masuk ke jurusan matematika adalah mereka yang memiliki identitas gender maskulin atau tomboi sebagai usaha mengasosiasikan diri dengan citra matematika yang susah. Citra matematika yang diajarkan oleh institusi pendidikan formal merupakan refleksi cara pandang sains dominan yang lebih menekankan kebenaran rasional-empiris tunggal, dualisme dan aspek instrumental sains.

Melalui kajian dan penelusuran literatur, belum ada penelitian dengan 
tema spesifik mengenai perempuan dan matematika yang pernah dilakukan untuk konteks Indonesia dari perspektif adil gender. Dengan begitu, penelitian ini akan menyediakan titik awal bagi penelitian serupa di tempat dan konteks sosial yang berbeda. Secara umum, mata pelajaran matematika merupakan momok bagi siswa dan bukan bidang yang banyak diminati siswa SMU. Secara khusus, perempuan cenderung menjauhi bidang itu karena dalam struktur patriarkhi dan cara pandang sains yang dominan.

Hasil penelitian TIMSS (Trends in International Mathematics and Science Study) menunjukkan tingkat literasi siswa di seluruh dunia dalam mempelajari matematika dan sains. TIMSS adalah studi internasional untuk kelas IV dan VIII dalam bidang Matematika dan Sains. TIMMS dilaksanakan untuk mengetahui tingkat pencapaian siswa berbagai negara di dunia sekaligus memperoleh informasi yang bermanfaat tentang konteks pendidikan Matematika dan Sains. TIMSS dilaksanakan secara berkala di 50 negara juga dikoordinasikan oleh IEA, suatu badan kerjasama internasional independen untuk institusi dan badan pemerintah yang telah melakukan studi prestasi lintas negara sejak tahun 1959. TIMSS pertama kali diselenggarakan pada tahun 1995 kemudian 1999, setiap empat tahun sekali TIMSS memberikan kesempatan pada Negara peserta untuk memperoleh informasi tentang prestasi siswa di bidang Matematika dan Sains.

Dari hasil riset TIMSS pada umumnya, siswa perempuan memperoleh nilai rata-rata yang lebih tinggi di semua negara terkecuali di Liechtenstein. Perbedaan itu rata-rata mencapai 34 poin, tetapi di Austria, Finlandia, Jerman, Islandia, Norwegia, Polandia, Serbia, dan Thailand, siswa perempuan mengungguli siswa laki-laki lebih dari 40 poin. Siswa di Islandia memperlihatkan perbedaan pencapaian yang paling tinggi, dengan perbedaan mencapai 58 poin.

Pada literasi matematika, pencapaian prestasi siswa perempuan tidak terlalu jauh berbeda dibandingkan dengan siswa laki-laki pada hampir semua negara peserta, seperti di Islandia, dan sebagian di Thailand, Serbia, Belanda, dan Indonesia. Pada studi TIMSS tahun 1994 -1995, untuk Kelas 4, perbedaan gender juga tidak terlalu signifikan dari 16 negara peserta hanya pada negara Islandia satu-satunya negera OECD yang siswa perempuannya secara konsisten lebih baik daripada siswa laki-laki. Di Australia, Aus-tria, Belgia, Jepang, Belanda, Norwegia, dan Polandia, seperti halnya di negara non-OECD Hongkong-China, Latvia, Serbia, Thailand, dan Indonesia, perbedaan gender secara keseluruhan tidaklah terlalu signifikan.

Hal ini mengindikasikan bahwa keragaman minat, bakat, gaya dan 
strategi belajar, dan bahkan kemampuan tersembunyi (underlying capacities) siswa Indonesia dalam mempelajari matematika tidak berbeda jauh antara laki-laki dan perempuan. Dapat juga diduga bahwa konteks sosial dan budaya memerankan peranan yang sangat penting dalam pelaksanaan program pendidikan pada umumnya, baik pada pendidikan formal maupun non-formal.

Hasil penelitian di atas juga didukung dari hasil penelitian PISA pada tahun 2000 juga menunjukkan pencapaian siswa laki-laki dan perempuan dalam literasi sains menunjukkan tidak adanya perbedaan yang signifikan dalam literasi matematika.

\section{Kesimpulan}

Pencapaian prestasi siswa perempuan pada literasi matematika tidak terlalu jauh berbeda dibandingkan dengan siswa laki-laki. Hal ini mengindikasikan bahwa keragaman minat, bakat, gaya dan strategi belajar, dan bahkan kemampuan tersembunyi (underlying capacities) siswa dalam mempelajari matematika tidak berbeda jauh antara laki-laki dan perempuan. Dapat juga diduga bahwa konteks sosial dan budaya memerankan peranan yang sangat penting dalam pelaksanaan program pendidikan pada umumnya, baik pada pendidikan formal maupun non-formal.

\section{DAFTAR PUSTAKA}

Departemen Pendidikan Nasional. (2004). Keterampilan Dasar untuk Hidup. Literasi Membaca, Matematika, \& Sains. Laporan Program for International Student's Assessment. Jakarta: Pusat Penilaian Pendidikan.

Ikarowina, T. 2008. Remaja Perempuan tidak PD dengan Kemampuan Matematika. Media Indonesia.com. (diakses 27 nopember 2008).

Kirsch, Irwin S., Ann Jungeblut, Lynn Jenkins, \& Andrew Kolstad. 1993. Adult Literacy in America. Washington, D.C.: National Center for Educational Statistics.

Mullis, Ina V.S., Ann M. Kennedy, Michael O. Martin, \& Marian Sainsbury 20-06. PIRLS 2006 Assessment Framework \& Specifications. 2nd 
Ed. TIMSS \& PIRLS International Study Center. Chestnut Hill, MA: Boston College.

Nurfajri dan Nugroho, N.B., 2008. Anak Perempuan Lebih Jago Matematika. Jurnal TechnoScience, www.okezone.com. (diakses 28 nopember 2008).

Tharp, R. G., \& Gallimore, R. 1988. Rousing minds to life: Teaching, Learning and schoolling in social context. New York: Cambridge University Press.

Yusuf, S. 2006. Perbandingan Gender Dalam Prestasi Literasi Siswa Indnesia. Bandung: Universitas Pendidikan Indonesia,. 